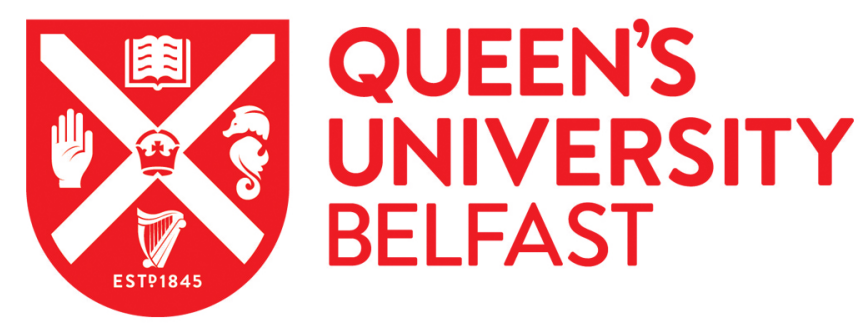

\title{
Production of polyclonal antibodies directed to recombinant methionyl bovine somatotropin
}

Suárez-Pantaleón, C., Huet, A. C., Kavanagh, O., Lei, H., Dervilly-Pinel, G., Le Bizec, B., Situ, C., \& Delahaut, P. (2013). Production of polyclonal antibodies directed to recombinant methionyl bovine somatotropin. Analytica Chimica Acta, 761, 186-193. https://doi.org/10.1016/j.aca.2012.11.041

Published in:

Analytica Chimica Acta

Document Version:

Peer reviewed version

Queen's University Belfast - Research Portal:

Link to publication record in Queen's University Belfast Research Portal

\section{Publisher rights}

This is the author's version of a work that was accepted for publication in Analytica Chimica Acta. Changes resulting from the publishing process, such as peer review, editing, corrections, structural formatting, and other quality control mechanisms may not be reflected in this document. Changes may have been made to this work since it was submitted for publication. A definitive version was subsequently published in Analytica Chimica Acta, Vol. 761, 25/01/2013

\section{General rights}

Copyright for the publications made accessible via the Queen's University Belfast Research Portal is retained by the author(s) and / or other copyright owners and it is a condition of accessing these publications that users recognise and abide by the legal requirements associated with these rights.

Take down policy

The Research Portal is Queen's institutional repository that provides access to Queen's research output. Every effort has been made to ensure that content in the Research Portal does not infringe any person's rights, or applicable UK laws. If you discover content in the Research Portal that you believe breaches copyright or violates any law, please contact openaccess@qub.ac.uk. 


\section{Accepted Manuscript}

Title: Production of polyclonal antibodies directed to recombinant methionyl bovine somatotropin

Authors: C. Suárez-Pantaleón, A.C. Huet, O. Kavanagh, H. Lei, G. Dervilly-Pinel, B. Le Bizec, C. Situ, Ph. Delahaut

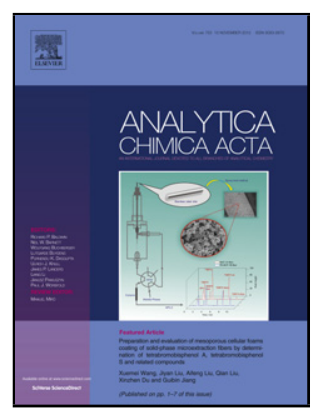

PII:

S0003-2670(12)01718-7

DOI: doi:10.1016/j.aca.2012.11.041

Reference: ACA 232246

To appear in: Analytica Chimica Acta

Received date: 28-6-2012

Revised date: 14-11-2012

Accepted date: $19-11-2012$

Please cite this article as: C. Suárez-Pantaleón, A.C. Huet, O. Kavanagh, H. Lei, G. Dervilly-Pinel, B. Le Bizec, C. Situ, Ph. Delahaut, Production of polyclonal antibodies directed to recombinant methionyl bovine somatotropin, Analytica Chimica Acta (2010), doi:10.1016/j.aca.2012.11.041

This is a PDF file of an unedited manuscript that has been accepted for publication. As a service to our customers we are providing this early version of the manuscript. The manuscript will undergo copyediting, typesetting, and review of the resulting proof before it is published in its final form. Please note that during the production process errors may be discovered which could affect the content, and all legal disclaimers that apply to the journal pertain. 

somatotropin HIGHLIGHTED

$6{ }^{a}$ Centre d'Economie Rurale (CER Groupe), Département Santé, Rue du Point du Jour 8, 76900 Marloie, Belgium.

8 b Institute of Agri-Food and Land Use, School of Biological Sciences, Queen's University

9 Belfast, Northern Ireland, United Kingdom.

$10{ }^{\mathrm{c}}$ South China Agricultural University, Institute of Food Safety and Quality, WuShan Street, 11 Guangzhou, 510642, P. R. China.

12 d LUNAM Université, Oniris, Laboratoire d'Étude des Résidus et Contaminants dans les

13 Aliments (LABERCA), Nantes, F-44307, France.

14 AUTHOR EMAIL ADDRESS

15 Celia Suárez-Pantaleón. Email: c.suarez@,cergroupe.be

16 Anne-Catherine Huet. Email: ac.huet@cergroupe.be

17 Owen Kavanagh. Email: o.kavanagh@qub.ac.uk

18 Hongtao Lei. Email: hongtao@scau.edu.cn

19 Gaud Dervilly-Pinel: gaud.pinel@oniris-nantes.fr

20 Bruno Le Bizec: bruno.lebizec@oniris-nantes.fr

$21 \quad$ Chen Situ. Email: c.situ@qub.ac.uk

22 Philippe Delahaut. Email: p.delahaut@cergroupe.be 


\section{*CORRESPONDING AUTHOR INFORMATION}

Centre d'Economie Rurale (CER Groupe), Département Santé, Rue du Point du Jour 8, 6900 Marloie, Belgium.

Phone: +32(0) 84310090

Fax: +32(0) 84316108

E-mail: p.delahaut@,cergroupe.be

\section{Abstract}

The administration of recombinant methionyl bovine somatotropin (rMbST) to dairy cows to increase milk yield remains a common practice in many countries including the USA, Brazil, Mexico, South Africa and Korea, whereas it has been forbidden within the European Union (EU) since 1999. A rapid screening immunoanalytical method capable of the unequivocal determination of rMbST in milk would be highly desirable in order to effectively monitor compliance with the EU-wide ban for home-made or imported dairy products. For decades, the production of specific antibodies for this recombinant isoform of bovine somatotropin (bST) has remained elusive, due to the high degree of sequence homology between both counterparts (e.g. methionine for rMbST in substitution of alanine in bST at the $N$-terminus). In this study, we compared several immunizing strategies for the production of specific polyclonal antibodies (pAbs), based on the use of the full-length recombinant protein, an rMbST $N$-terminus peptide fragment and a multiple antigen peptide (MAP) which consists of an oligomeric branching lysine core attached to the first two $N$-terminus amino acids of rMbST, methionine and phenylalanine (MF-MAP). The immunization with KLH-conjugated MF-MAP led to the production of the $\mathrm{pAb}$ with the highest $\mathrm{rMbST} / \mathrm{bST}$ recognition ratio amongst the generated battery of antibodies. The pAb exhibited a specific binding ability to rMbST in a competitive antigen-coated ELISA format, which avidity was further improved 
47 after purification by rMbST $N$-terminus peptide-based affinity chromatography. These results

48 suggest that immunodiscrimination between structurally related proteins can be achieved 49 using immuno-enhanced immunogens such as MAPs.

50

51 Keywords: recombinant methionyl bovine somatotropin, polyclonal antibodies, 52 immunodiscrimination, multiple antigen peptide.

53

54 Abbreviations: bST, bovine somatotropin; rMbST, recombinant methionyl bovine 55 somatotropin; MAP, multiple antigen peptide; pAb, polyclonal antibody. 


\section{Introduction}

Bovine somatotropin (bST), with the majority isoform of 191-amino acid protein and a molecular weight of 21802 Daltons (Table 1), is produced and secreted by the anterior pituitary gland. Through a complex network system, the somatotropic axis, this hormone regulates several physiological processes involved in metabolism, growth and reproduction [1]. It is well documented that the exogenous administration of bST redirects nutritional partitioning towards milk synthesis in dairy cows, which is therefore translated into an increase in milk production ranging from 10 to $40 \%$ [2,3]. Genetically-engineered or recombinant isoforms of the bovine somatotropin have been developed and produced since the early 1990's. Recombinant methionyl bST (rMbST; Table 1), initially commercialized by Monsanto and then by Elanco (Animal Division of Eli Lilly and Company) under the trade name of Posilac ${ }^{\circledR}$, is the only commercial product approved by the Food and Drug Administration (FDA) in the USA and by the corresponding competent authorities in Brazil, Mexico, South Africa and Korea. However, its marketing and utilization as well as the trade of dairy products obtained from rMbST-treated animals, are prohibited within the EU [4], and other countries such as Japan, China, Australia, New Zealand or Canada. Along with the ongoing hormone debates between the EU and the USA, controversy has surrounded rMbST since it became commercially available in 1994, with growing concern about the implications of the administration of this synthetic protein on human and animal health and welfare. Several adverse effects reported for treated animals include diminished fertility and an increased occurrence of lameness and clinical mastitis $[5,6]$, which requires additional antibiotic treatments that may cause further food safety concern regarding antibiotic residues in dairy and other food products. Extensive use of antibiotics in modern agricultural farming has also been linked to the development and emergence of antibiotic resistance that is currently affecting both human and veterinary medicine worldwide [7]. Moreover, 
administration of somatotropin raises the concentration of Insulin-like Growth Factor 1 (IGF1) in milk [8]. Elevated circulating levels of IGF-1 have been associated with a higher risk of developing several types of cancer $[9,10]$. However, studies correlating the intake of milk from rMbST-treated animals with human diseases are still lacking.

In order to control illegal administration of rMbST and to ensure high quality and safety of milk and consumer protection, reliable analytical methodologies capable of unambiguous identification of the synthetic methionyl growth hormone in milk are required. Current analytical methods for determination of $\mathrm{rMbST}$ rely on instrumental technologies such as HPLC-MS/MS [11-14]. Despite the fact that chromatographic systems are highly sensitive and specific, these techniques often limit their applications for rapid screening of a large number of samples due to the requirement of extensive sample preparation time and sophisticated instrumentation which is also laboratory-based. Immunoanalytical methods, in particular Enzyme-Linked Immunosorbent Assays (ELISA), are widely used as rapid screening tools for routine monitoring of food contaminants and residues, owing to their simplicity, cost-effectiveness and capabilities of performing high-throughput analysis. Two different immunoanalytical approaches have been adopted for the detection of rMbST. By the direct strategy, the presence of the native and the recombinant isoforms is determined simultaneously in biological fluids [15-17], whereas the indirect approach is based on the analysis of biomarkers of which their concentration is increased upon rMbST administration.

101 IGF-1 has been the traditional target measured for this purpose [8, 17-20]. Methods based on 102 the detection of anti-rMbST immunoglobulins in treated cows have also been published [21, 22]. Nevertheless, the direct analysis of $\mathrm{rMbST}$ itself is highly preferable, in order to circumvent problems associated with inter and intra-individual variation of biomarkers expression levels, which can lead to misinterpretation of results. 
106 To date, no specific immunoassays have been described for the detection of rMbST. The high

107 sequence homology displayed by the recombinant and the native somatotropins (methionine

108 in substitution of alanine at the $N$-terminus) has greatly hindered the successful production of

109 rMbST-selective antibodies. The strategy most often used entails the immunization with the

110 complete recombinant protein [21, 23-25]. Nevertheless, the antibodies produced following

111 this procedure have generally failed in their capacity to immunodiscriminate between bST

112 and $\mathrm{rMbST}$, while a 2-fold increased affinity factor towards rMbST was described for the

113 mAb-based sandwich assay developed by Erhard et al [23]. Considering that only one amino

114 acid of difference at the $N$-terminus is encountered, the immunization with the whole protein

115 most likely leads to the production of antibodies directed towards shared epitopes in both

116 counterparts, $\mathrm{bST}$ and $\mathrm{rMbST}$, therefore being unable to specifically recognize the latter. On

117 the other hand, a frequently accomplished practice for raising antibodies against proteins is

118 based on the use of immunizing synthetic peptide fragments which mimic concrete sequences

119 within the target [26-28]. The immunization with a synthetic peptide representing the

120 differential $\mathrm{N}$-terminus of rMbST could a priori focus the immune response towards the

121 recognition of the characteristic epitope of the protein. Castigliego et al described for the first time the production of a mAb by using a synthetic nine amino acid rMbST $\mathrm{N}$-terminusmimicking peptide coupled to KLH as immunogen [16]. Despite showing a 3-fold higher affinity towards $\mathrm{rMbST}$ than to $\mathrm{bST}$, complete immunodiscrimination was not yet possible by using the developed immunoassays. As an alternative to monovalent peptides, multiple antigen peptides (MAPs) or multimerized peptides, have been used as immunogens since they were developed in 1988 [29], especially in the area of vaccine development [30-32]. MAPs have been shown to efficiently improve the immunogenicity of a particular antigen, thus eliciting a stronger immune response, as a consequence of the presentation of multiple

130 copies to the immune system [33]. Furthermore, it has been reported that the resulting 
131 immune response is generally mono-specific and more homogeneous [34]. The production of

132 pAbs targeted at vertebrate somatotropins using a synthetic MAP constituted by several

133 copies of an 18 amino acid highly conserved domain proximal to the $C$-terminus of the

134 protein has already been published [35]. To our knowledge this system has never been

135 applied before for the production of rMbST-specific antibodies.

136 In the present work several immunization strategies have been compared for the production

137 of anti-rMbST rabbit pAbs. The immunization with an octavalent synthetic rMbST $N$ -

138 terminus dipeptide-mimicking MAP, followed by affinity purification with a synthetic

$139 \mathrm{rMbST} N$-terminus-mimicking linear peptide, resulted in the production of a pAb capable of

140 specifically differentiating between the recombinant and the native somatotropins in a

141 competitive ELISA format.

\section{2. Experimental}

\section{$143 \quad$ 2.1. Reagents and instrumentation}

144 3-(cyclohexylamino)-1-propanesulfonic acid (CAPS), 2-( $N$-morpholino)ethanesulfonic acid, 2-(4-morpholino)ethanesulfonic acid (MES), 1-ethyl-3-(3-dimethylaminopropyl)

146 carbodiimide (EDC) and N-hydroxysuccinimide (NHS) were obtained from Sigma Aldrich

147 (St. Louis, MO, USA). Succinimidyl 4-[N-maleimidomethyl]cyclohexane-1-carboxylate

148 (sulfo-SMCC) was acquired from Thermo Fisher Scientific (Rockford, IL, USA). Slide-A-

149 Lyzer dialysis cassettes and Zeba 7kDa Desalting columns from Thermo Fisher Scientific

150 (Rockford, IL, USA) were used for the purification of the immunizing conjugates. Keyhole

151 limpet hemocyanin (KLH) carrier protein, complete and incomplete Freund's Adjuvants, the

152 bicinchoninic acid (BCA) test kit were from Sigma Aldrich (St. Louis, MO, USA). rMbST N-

153 terminus dipeptide-mimicking MAP, MF-MAP-C (Figure 1), was acquired from GenScript 
154 (Piscataway, NJ, USA). Synthetic rMbST $N$-terminus-mimicking linear peptides EP091213 (amino acid sequence: $\mathrm{H}_{2} \mathrm{~N}-\mathrm{Met}-\mathrm{Phe}-\mathrm{Pro}-\mathrm{Ala}-\mathrm{Met}-\mathrm{Ser}-\mathrm{Leu}-\mathrm{Ser}-\mathrm{Gly}-\mathrm{Leu}-\mathrm{Phe}-\mathrm{Ala}-\mathrm{Asn}-\mathrm{Ala}-$ Val-Leu-Arg-Cys-COOH) and EP093536 (amino acid sequence: $\mathrm{H}_{2} \mathrm{~N}-$ Met-Phe-Pro-AlaMet-Ser-Leu-Ser-Gly-Leu-Phe-Cys-CONH 2 ), used for animal immunization and antibody purification, respectively, were purchased from Eurogentec S.A. (Seraing, Belgium). Affinity columns packed with Protein A Sepharose 4 Fast Flow gel purchased from GE Healthcare were used for the purification of rabbit antibodies. EP093536 peptide affinity column was prepared using Toyopearl AF-Amino-650M gel from Tosoh Bioscience GmbH (Stuttgart, Germany). Maleimidobenzoic acid $N$-hydroxysuccinimide ester (MBS) and streptavidin poly-HRP (STV-pHRP) were acquired from Thermo Fisher Scientific (Rockford, IL, USA). Centricon Plus-20 ultracentrifugation concentration devices (molecular cut-off $3 \mathrm{~K}$ ) were purchased from Millipore (Billerica, MA, USA). Peroxidase-conjugated polyclonal goat antirabbit immunoglobulin (GAR-HRP) was purchased from Sigma Aldrich. Biotin-SPconjugated polyclonal goat anti-rabbit IgG $(\mathrm{H}+\mathrm{L})(\mathrm{GAR}-\mathrm{b})$ was obtained from Jackson Immunoresearch Europe (Suffolk, United Kingdom). Gelatin was from Merck (Darmstadt, Germany). Bovine serum albumin (BSA) was from Sigma Aldrich. Lactoferrin from bovine milk was provided by Taradon Laboratory SPRL (Tubize, Belgium). $\beta$-lactoglobulin from bovine milk was from Sigma Aldrich. Casein from bovine milk was purchased from Merck. Bovine prolactin was from the National Institute of Health (NIH, USA). Bovine placental 173 lactogen was provided by Jean-François Beckers from the University of Liège (Liège, 174 Belgium). Pepstatin, EDTA and acetic acid were from Sigma Aldrich (St. Louis, MO, USA). Sequencing-grade modified trypsin (EC 3.4.21.4) was from Promega (Madison, WI, USA). Ninety-six-well flat-bottom Nunc Maxisorp polystyrene ELISA plates were purchased from

177 Nunc (Roskilde, Denmark). ELISA plate washer model 1575 Immunowash was from Bio178 Rad Laboratories (Hercules, CA, USA). 3,3',5,5'-Tetramethylbenzidine $/ \mathrm{H}_{2} \mathrm{O}_{2}$ solution was 
179 from BioFX Laboratories (Owings Mills, MD, USA). ELISA absorbance was monitored at $180450 \mathrm{~nm}$ using a Multiskan EX reader provided by Thermo Fisher Scientific (Zellik, Belgium). 181 Buffers and solutions: 1) Coating buffer $(C B)$ : $50 \mathrm{mM}$ sodium carbonate-bicarbonate buffer 182 (pH 9.6). 2) Blocking solution: CB containing 0.5\% (w/v) gelatin. 3) EIA buffer: $5.6 \mathrm{mM}$ $\mathrm{Na}_{2} \mathrm{HPO}_{4} \cdot 2 \mathrm{H}_{2} \mathrm{O}, 0.9 \mathrm{mM} \mathrm{NaH} \mathrm{PO}_{4} \cdot 2 \mathrm{H}_{2} \mathrm{O}, 150 \mathrm{mM} \mathrm{NaCl}$, (pH 7.4), containing $0.02 \%$ (w/v) gelatin, $0.005 \% \quad(\mathrm{v} / \mathrm{v})$ Tween 20, $0.001 \% \quad(\mathrm{w} / \mathrm{v})$ 8-Anilino-1-naphthalenesulfonic acid ammonium salt, $0.005 \%$ (w/v) ascorbic acid, $0.01 \%(\mathrm{w} / \mathrm{v})$ thimerosal. 4) Washing solution: $150 \mathrm{mM} \mathrm{NaCl}$, containing $0.05 \%(\mathrm{v} / \mathrm{v})$ Tween 20. 5) PBS: $44 \mathrm{mM}$ sodium phosphate, $6 \mathrm{mM}$ potassium phosphate, $154 \mathrm{mM} \mathrm{NaCl}$, (pH 7.4). 6) PBST: PBS containing $0.05 \%(\mathrm{v} / \mathrm{v})$ Tween 20.

\subsection{Somatotropin standards}

190 Pituitary bovine somatotropin (bST) was purchased from the National Hormone and Peptide 191 Program (NHPP), Harbor-UCLA Medical Centre (Torrance, CA, USA). Pituitary porcine somatotropin (pST) was from Sigma Aldrich. Recombinant methionyl equine somatotropin (rMeST, EquiGen-5) was from Bresagen Ltd. (Thebarton, Australia). Recombinant methionyl bovine somatotropin $(\mathrm{rMbST})$ was extracted from the slow release formula of Lactotropin ${ }^{\circledR}$ syringes provided by Elanco (Greenfield, IN, USA) as described previously with modifications [25]. Briefly, $20 \mathrm{~mL}$ of $50 \mathrm{mM}$ CAPS buffer (pH $11.0 ; 100 \mathrm{mM} \mathrm{NaCl})$ was added to $500 \mathrm{mg}$ of syringe content. The syringe content was emulsified by vortex for 1 minute and then by sonication for 10 minutes in a water bath. The emulsion was immediately centrifuged $(1000 \times \mathrm{g}, 10 \mathrm{~min})$ and the transparent layer containing rMbST was removed from

200 the white excipient layer. To ensure maximum recovery of rMbST a further $10 \mathrm{~mL}$ of CAPS

201 buffer was emulsified with the remaining white excipient and mixed by vortex and sonication and centrifuged as previously described. The rMbST phases were pooled together and filtered 
using a $0.45 \mu \mathrm{m}$ cellulose filter. The rMbST solution was immediately aliquoted, lyophilized and stored at $-20{ }^{\circ} \mathrm{C}$ until use. The protein concentration of the extracted $\mathrm{rMbST}$ was determined using a BCA assay and confirmed by liquid chromatography coupled to highresolution mass spectrometry measurement $\left(\mathrm{LC}-\mathrm{HRMS}^{\mathrm{n}}\right.$; results not shown), as described previously [11]. A tryptic digestion was performed overnight at $37{ }^{\circ} \mathrm{C}$ in $120 \mu \mathrm{L}$ of $50 \mathrm{mM}$ ammonium bicarbonate, $10 \mathrm{mM}$ EDTA and $1 \mu \mathrm{M}$ pepstatin ( $\mathrm{pH}$ 7.9) with $2 \mu \mathrm{g}$ of enzyme. The extracts were then evaporated, reconstituted in $40 \mu \mathrm{L}$ of water/acetonitrile $70: 30(\mathrm{v} / \mathrm{v})$ with $0.2 \%(\mathrm{v} / \mathrm{v})$ formic acid and analyzed by LC-HRMS ${ }^{\mathrm{n}}$. Separation of the peptides was achieved on a Symmetry $3002.1 \mathrm{~mm} \times 150 \mathrm{~mm} \mathrm{C4}$ column packed with $3.5 \mu \mathrm{m}$ beads, 300

$212 \AA$ pore size (Waters, Milford, USA). The solvent flow rate was set at $300 \mu \mathrm{L} \mathrm{min}{ }^{-1}$. Peptides 213 were separated using acetonitrile containing $0.2 \%(\mathrm{v} / \mathrm{v})$ formic acid (A) and water containing $0.2 \%(\mathrm{v} / \mathrm{v})$ formic acid (B) as mobile phase. The elution gradient started with $10 \% \mathrm{~A}$ increasing to $50 \%$ in $5 \mathrm{~min}$, then decreasing to initial conditions in $5 \mathrm{~min}$ and remaining at $10 \%$ A for 5 more minutes. A divert valve was used to let the sample pass into the instrument

217 from 4.5 to 9 min. The typical expected retention time was 6.7 and 6.9 min for the rMbST $N$ -

218 terminus peptide and the rMeST $N$-terminus peptide (used as internal standard), respectively.

219 The MS instrument was a linear ion trap coupled to an orbitrap allowing high resolution measurements (LTQ-Orbitrap ${ }^{\mathrm{TM}}$, Thermo Electron, Bremen, Germany), fitted with an electrospray ion source (ESI). The API interface was operated in positive ion mode. A sample volume of $20 \mu \mathrm{L}$ was loaded onto the column using the autosampler. A column heater was used to ensure a stable column temperature of $30{ }^{\circ} \mathrm{C}$. Mass spectrometric analyses were performed in the following working conditions: capillary voltage was set at $42 \mathrm{~V}$, source voltage at $5 \mathrm{kV}$ and capillary temperature at $300{ }^{\circ} \mathrm{C}$. Nitrogen was used as sheath, auxiliary and sweep gas at flow rates of 50,10 and 10 (arbitrary unit), respectively. The linear ion trap mass spectrometer was set to select the ions 933.5 and 913.3 corresponding to $[\mathrm{M}+2 \mathrm{H}]^{2+}$ of 
the tryptic $N$-terminus peptides of rMeST and rMbST, respectively. Collision energy of $20 \%$ (arbitrary unit) was applied to the ion 933.5 and $18 \%$ to the ion 913.3 . The detection of the resulting product ions was performed in the orbitrap at a resolution of 30000 . Acquisition was performed in full scan mode from $\mathrm{m} / \mathrm{z} 500$ to 1500 . Data were collected and analyzed with the Xcalibur software (Thermo Electron).

\subsection{Preparation of immunogens}

234 i) Coupling of $r M b S T$ to $K L H$ : the immunogen rMbST-KLH was obtained using the EDC/NHS reaction. Briefly, $20 \mathrm{mg}$ of EDC and $10 \mathrm{mg}$ of NHS were dissolved in $100 \mu \mathrm{L}$ of 0.05 M MES, $0.5 \mathrm{M} \mathrm{NaCl}$ buffer (pH 4.7). The solution of EDC/NHS was added to $10 \mathrm{mg}$ of $\mathrm{rMbST}$ and allowed to react for $10 \mathrm{~min}$. The EDC/NHS-activated rMbST was added slowly with stirring to $1 \mathrm{~mL}$ of PBS (pH 7.4) containing $20 \mathrm{mg}$ of the carrier protein. The conjugation reaction was performed overnight under stirring at room temperature.

ii) Coupling of cysteine-containing rMbST N-terminus peptides to KLH: synthetic rMbST $N$-terminus-mimicking peptides, EP091213 and MF-MAP-C (Figure 1), were conjugated to KLH via their cysteine residues using the commercial sulfo-SMCC conjugation kit (Fisher Scientific UK, Leicestershire, UK) according to manufacture instructions.

244 All of the immunogens were purified by overnight dialysis (Slide-A-Lyzer Dialysis cassettes; $3 \mathrm{kDa}$ cut-off) against a $0.9 \%(\mathrm{w} / \mathrm{v}) \mathrm{NaCl}$ solution. The protein concentration was estimated by BCA assay and the conjugates were aliquoted, lyophilized and stored at $-20{ }^{\circ} \mathrm{C}$.

\subsection{Polyclonal antibody production}

248 Polyclonal antibodies were produced in New Zealand white SPF (specific pathogen free)

249 rabbits. A summary of the production of the pAbs is shown in Table 2. Rabbits were 250 immunized by subcutaneous injection with $1 \mathrm{~mL}$ of a 1:1 emulsion of a saline solution containing the immunogen and Freund's complete adjuvant (first dose) or Freund's 
incomplete adjuvant (subsequent doses). Generally $0.2 \mathrm{mg}$ of immunogen were administered, with the exception of $\mathrm{rMbST}-\mathrm{KLH}$, for which $0.1 \mathrm{mg}$ were used. Immunizations were performed initially in intervals of 15 days, and then monthly after the third boost. A test blood sample was obtained from every rabbit prior to immunization, and then 10 days after each immunization from the $3^{\text {rd }}$ boost onward. Pre-immune and immune sera were obtained by coagulation and centrifugation of the blood samples. Working solutions were prepared in a 1:1 mixture of EIA buffer and ethylene glycol, and they were stored at $-20{ }^{\circ} \mathrm{C}$.

\subsection{Peptide-based affinity purification of the polyclonal antibody MU11}

The pAb MU11 was purified by affinity chromatography using a peptide EP093536 column.

AF-Amino-650M gel were activated with MBS, followed by the coupling of the maleimide activated $-\mathrm{NH}_{2}$ moieties with the $-\mathrm{SH}$ group of the cysteine in the peptide EP093536. $2.5 \mathrm{~mL}$ of gel in $1.25 \mathrm{~mL}$ of $50 \mathrm{mM}$ sodium phosphate buffer $(\mathrm{pH} 6)$ were incubated for $30 \mathrm{~min}$ at room temperature with orbital agitation with $175 \mu \mathrm{L}$ of a MBS solution in $\mathrm{N}, \mathrm{N}$ dimethylformamide (DMF; $15 \mathrm{mg} / \mathrm{mL})$. The gel suspension was then centrifuged $(1800 \times \mathrm{g}, 2$ min) and supernatant was discarded. The gel was washed 3 times with $2.5 \mathrm{~mL}$ of $10 \times \mathrm{PBS}$ ( $\mathrm{pH}$ 7.4), and resuspended in $1.25 \mathrm{~mL}$ of PBS. Immediately prior to use, the peptide EP093536 $(8.4 \mathrm{mg})$ was dissolved in $1.4 \mathrm{~mL}$ of a mixture of DMF:PBS (30:70, v/v). The peptide solution was added to the gel suspension and incubated for $18 \mathrm{~h}$ at room temperature under orbital agitation. After centrifugation, the gel was resuspended in $2.5 \mathrm{~mL}$ of PBS and

272 packed into a purification column. The peptide EP093536 affinity column was stored at $4{ }^{\circ} \mathrm{C}$.

273 ii) Purification of the pAb MU11 by peptide-based affinity chromatography: prior to the peptide-based purification, the immunoglobulin fraction of the rabbit pAb MU11 was isolated

275 from the crude serum $(5 \mathrm{~mL})$ by protein A affinity chromatography. The recovered 
immunoglobulin fractions were then dialyzed in PBS $\left(18 \mathrm{~h}, 4^{\circ} \mathrm{C}\right)$, and concentrated in a

277 Centricon Plus-20 device $\left(4600 \times \mathrm{g}, 30 \mathrm{~min}, 4{ }^{\circ} \mathrm{C}\right)$ up to a final volume of $1 \mathrm{~mL}$. The solution

278 containing the immunoglobulins was loaded onto the peptide EP093536 column pre279 conditioned by the addition of 5 volumes of PBS $(20 \mathrm{~g} / \mathrm{L} \mathrm{NaCl})$, and incubated at room 280 temperature for $3 \mathrm{~h}$ with orbital agitation. The non-retained immunoglobulins were eluted by 281 washing with PBS $(20 \mathrm{~g} / \mathrm{L} \mathrm{NaCl})$. The elution of the peptide-specific immunoglobulins was 282 conducted using $100 \mathrm{mM}$ glycine buffer ( $\mathrm{pH}$ 2.5). The column was regenerated by addition of 5 volumes of PBS and stored at $4{ }^{\circ} \mathrm{C}$ in $20: 80$ methanol:distilled water. Those fractions containing immunoglobulins, as determined spectrophotometrically at $280 \mathrm{~nm}$, were pooled and dialyzed overnight in PBS containing $0.001 \%(\mathrm{w} / \mathrm{v}) \mathrm{NaN}_{3}$ at $4{ }^{\circ} \mathrm{C}$. The antibody solutions (specific and non-specific fractions) were concentrated as described above, and the concentration was estimated by the BCA protein assay test. The antibodies were stored at -20 ${ }^{\circ} \mathrm{C}$ in PBS containing $0.001 \%(\mathrm{w} / \mathrm{v})$ of thimerosal and $10 \%(\mathrm{w} / \mathrm{v})$ of BSA.

\subsection{Antigen-coated competitive ELISA}

i) General assay procedure: ELISA plates were coated overnight at room temperature with $100 \mu \mathrm{L}$ of the standard solution [rMbST or bST] prepared in coating buffer (ranging from 0.25 to $16 \mu \mathrm{g} / \mathrm{mL}$ ). The blocking of the plates was performed by incubation for $2 \mathrm{~h}$ at 37 ${ }^{\circ} \mathrm{C}$ with $250 \mu \mathrm{L}$ of blocking solution. After the coating and the saturation steps, the plates were aspirated. In the competitive assay, $50 \mu \mathrm{L}$ of the antibody solution and $50 \mu \mathrm{L}$ of the standards prepared in EIA buffer were added and incubated for $1 \mathrm{~h}$ at $37{ }^{\circ} \mathrm{C}$. Then, $100 \mu \mathrm{L}$ of labeled secondary antibody prepared in EIA buffer (GAR-HRP at 1:2000) was added and incubated for $1 \mathrm{~h}$ at $37^{\circ} \mathrm{C}$. Plates were washed 5 times with washing solution between each incubation step. Finally, the retained peroxidase activity was revealed with $100 \mu \mathrm{L}$ of a 
ready-to-use TMB solution for $30 \mathrm{~min}$ in the darkness at room temperature. The enzymatic reaction was stopped by addition of $50 \mu \mathrm{L}$ of $1.8 \mathrm{~N} \mathrm{H}_{2} \mathrm{SO}_{4}$.

301 ii) Optimized assay procedure: the following procedure was used for the purified pAb

302 MU11. This protocol was based on the general assay procedure, with slight modifications. An

303 overnight pre-incubation of the antibody and the antigen (mixed at equal volumes in plastic

304 tubes) was performed at $4{ }^{\circ} \mathrm{C}$. Then, $100 \mu \mathrm{L}$ of the pre-incubated solutions were added to the 305 coated and blocked plates, and incubated for $30 \mathrm{~min}$ at $37{ }^{\circ} \mathrm{C}$. A biotin/streptavidin

306 amplification system was used, consisting of an initial incubation with $100 \mu \mathrm{L}$ of a 1:150000

307 dilution of GAR-b prepared in $\operatorname{PBST}\left(1 \mathrm{~h}, 37^{\circ} \mathrm{C}\right)$, followed by an additional incubation with

$308100 \mu \mathrm{L}$ of a 1:20000 dilution of STV-pHRP prepared in PBST containing $1 \%(\mathrm{w} / \mathrm{v})$ of BSA

$309\left(1 \mathrm{~h}, 37^{\circ} \mathrm{C}\right)$.

310 iii) Signal processing: Absorbance was monitored at $450 \mathrm{~nm}$. The signal intensity was

311 plotted against the standard concentration in a logarithmic scale, and the resulting sigmoidal

312 curves were mathematically fitted to a four-parameter logistic equation using the SigmaPlot

313 software package from SPSS Inc. (Chicago, IL, USA). The $\mathrm{IC}_{50}$ value, corresponding to the

314 standard concentration that generates a $50 \%$ reduction of the maximum signal intensity

$315\left(\mathrm{~A}_{\max }\right)$, was used for the estimation of the assay detectability. The limit of detection of the

316 assay (LOD) was determined as the concentration of standard that generates a 2 sd decrease of

317 the signal obtained at the zero dose of analyte $\left(\mathrm{A}_{0}-2 \mathrm{sd}\right)$. The absorbance values were

318 normalized using $\mathrm{A}_{0}$ as reference measure.

\section{2.7. Cross-reactivity study}

320 The capability of recognition by the peptide-purified antibody MU11 to pituitary bovine somatotropin (bST), pituitary porcine somatotropin (pST), recombinant methionyl equine somatotropin (rMeST), bovine serum albumin (BSA), lactoferrin, $\beta$-lactoglobulin, casein, 
323 bovine prolactin and bovine placental lactogen was evaluated by conducting competitive

324 experiments using the mentioned proteins as competitors. Cross-reactivity (CR) values were

325 calculated as follows: $\mathrm{CR}=\mathrm{IC}_{50(\mathrm{rMbST})} / \mathrm{IC}_{50 \text { (competitor) }} \times 100$.

326 3. Results and discussion

327 3.1. Immunogen description

328 In the present work several immunizing strategies for the production of anti-rMbST

329 antibodies were compared. The immunogens were categorized as i) complete recombinant

330 somatotropin (rMbST); ii) rMbST $N$-terminus-mimicking synthetic linear peptide; and iii)

331 rMbST $N$-terminus-mimicking synthetic MAP. In the case of the synthetic molecules (linear

332 peptide and MAP), the design comprised a $C$-terminus cysteine, an amino acid commonly

333 introduced for coupling purposes, via the side chain thiol group. The rMbST-mimicking

334 synthetic linear peptide EP091213 represents the first $17 \mathrm{~N}$-terminus amino acids of rMbST

$335\left(\mathrm{H}_{2} \mathrm{~N}-\mathrm{MFPAMSLSGLFANAVLRC}-\mathrm{COOH}\right)$. The rMbST-mimicking synthetic multiple

336 antigen peptide MF-MAP-C (Figure 1), displays in an arachnid-type manner eight units of

337 the first two $N$-terminus amino acids of rMbST, methionine and phenylalanine, with a weakly

338 immunogenic lysine ${ }_{\mathrm{n}}$ core. All of the immunogens were prepared by covalent conjugation of

339 the three mentioned molecules to the carrier protein KLH. In order to guarantee the

340 accessibility of the rMbST $N$-terminus characteristic portion of the antigens to the immune

341 system, different coupling chemistries were used for the preparation of the immunogens. In

342 the case of the recombinant whole protein, formation of amide bonds between the free

343 carboxylic groups of rMbST and the amine groups of KLH was conducted using the active

344 ester method. The peptide EP091213 and MF-MAP-C were conjugated using the 
345 heterobifunctional crosslinker sulfo-SMCC, by coupling each peptide to maleimide-activated 346 amine groups of $\mathrm{KLH}$ via the cysteine residue of their $C$-terminus.

347 By the immunization of rabbits with the three mentioned immunogens, 9 polyclonal 348 antibodies were obtained (Table 2).

\section{3.2. Preliminary antibody characterization}

350 The capability of immunodiscrimination of the 9 available pAbs between the native and the

351 recombinant methionyl somatotropins was initially assessed by a checkerboard titration procedure in the antigen-coated ELISA format using both proteins as coating antigens. As a first approach, the crude sera were analyzed without any further purification. As shown in Table 3, all three immunogens gave rise to a positive immune response. All of the antibodies, with only one exception (M10), recognized the native somatotropin and/or the recombinant methionyl isoform to a different extent. Despite immunization with rMbST-KLH generated the pAbs with the highest titers, these were unable to immunodiscriminate the recombinant methionyl isoform, therefore displaying a very similar binding behavior towards both somatotropins. From these results and those described in previous studies where the same

360 immunizing strategy was used [21, 23-25], it could be inferred that using the complete

361 recombinant protein as immunogen directs the immune response towards common antigenic determinants within the recombinant and the native isoforms, with the $\operatorname{rMbST} N$-terminus being "masked". This remark is of special relevance in the case of pAbs, representing a heterogeneous collection of antibodies with disparate profiles of selectivity, where the rMbST-specific sub-population, if produced, would consequently be in the minority. Finally, the immunogens consisting of rMbST $N$-terminus-mimicking synthetic peptides (both the linear peptide and the MAP), afforded the most promising results, as three of the produced pAbs exhibited a higher recognition towards rMbST, namely M9 for EP091213-KLH, and 
MU9 and MU11 for MF-MAP-SMCC-KLH. These antibodies were therefore selected for further studies.

371 In order to reduce background-associated problems encountered with the raw sera, the three 372 pAbs were purified by protein A affinity chromatography. A representative set of data of the

373 response to $\mathrm{rMbST}$ and $\mathrm{bST}$ of the mentioned protein A purified antibodies by checker-board 374 titration in the antigen-coated ELISA is displayed in Figure 2, including also one of the generic pAbs (BC8) for comparative purposes. The highest $\mathrm{rMbST} / \mathrm{bST}$ recognition ratio was observed for pAb MU11, therefore highlighting the superior efficiency of the immunogen based on the rMbST $N$-terminus-mimicking MAP coupled to KLH over the other strategies used. Despite the fact that suitable amino acid number in MAPs is usually considered to be comprised between 10 and 20 residues [35], the immunization with an rMbST $N$-terminus dipeptide-mimicking MAP has been proven to be sufficiently immunogenic to induce the production of anti-rMbST antibodies.

In conclusion, as previously reported by other authors regarding the production of antibodies directed to other targets $[33,36]$, the immunization with a MAP resulted in a stronger and/or more specific response than that generated by a mimicking monovalent peptide or the complete recombinant protein. According to the results herein presented, the rabbit pAb MU11 was chosen for the development of an anti-rMbST immunoassay.

\subsection{Competitive immunoassay based on the polyclonal antibody MU11}

Those combinations of antibody dilution/coating antigen (rMbST) affording adequate signal intensity (around 1 absorbance units), as determined by checker-board titration, were selected

390 to perform inhibition experiments using rMbST and bST as competitors. A preliminary experiment was carried out to determine the assay conditions generating the highest inhibition ratios for $\mathrm{rMbST}$. It was found that the introduction of a pre-incubation step of the 
antibody and the competitor in combination with a short period of time for the competitive step provided an improvement of the assay sensitivity (results not shown). Compensation of signal loss due to the reduction of the immunoreactive step time was achieved using a signal amplification system based on a biotinylated secondary antibody and HRP-labeled streptavidin. As shown in Figure 3, a specific response was displayed by the antibody MU11 towards rMbST, whereas no inhibition was observed when bST was used as competitor. All of the evaluated combinations afforded very similar inhibition ratios for rMbST, with an estimated $\mathrm{IC}_{50}$ value comprised between 500 and $5000 \mu \mathrm{g} \mathrm{L}^{-1}$. In order to improve the antibody performance in terms of sensitivity, the pAb was subjected to a further purification step using an $\mathrm{rMbST} N$-terminus-mimicking synthetic peptide-based affinity procedure. The affinity purification of antibodies produced against $\mathrm{rMbST}$ has been previously reported, although in all of the described methods the complete recombinant protein was used with this purpose $[16,17,21,25]$. The competitive standard curves for rMbST and bST, as well as the assay conditions and parameters obtained using the peptide-purified MU11 pAb in the most sensitive coating antigen/antibody dilution combination are included in Figure 4. By using the peptide-purified fraction of the pAb MU11 the assay sensitivity was greatly improved, being the resulting LOD for $\mathrm{rMbST}$ in buffer of $66 \mu \mathrm{g} \mathrm{L}^{-1}$. This result indicates that antigenbased affinity purification is a convenient strategy not only to isolate the immunoglobulin

411 sub-populations directed to a ligand, but also to modulate the overall avidity of a pAb, and

412 thus the assay sensitivity, as those immunoglobulins with the lowest affinity towards the 413 target are removed during the washing step. Levels of $\mathrm{rMbST} / \mathrm{bST}$ in fresh bovine milk after 414 administration of somatotropin slow release formulations have been reported to be below 5 $415 \mu \mathrm{g} \mathrm{L}^{-1}[15,37]$, in contrast to plasma or serum, where concentrations up to $120 \mu \mathrm{g} \mathrm{L} \mathrm{L}^{-1}$ have 416 been found [13]. Furthermore, common heat treatments to which commercial milk is 417 submitted prior to commercialization, such as pasteurization, reduce up to $90 \%$ the 
$418 \mathrm{rMbST} / \mathrm{bST}$ content $[14,37]$. In order to effectively monitor the presence of $\mathrm{rMbST}$ in milk

419 samples, further improvement of the MU11-based immunoassay herein presented is therefore

420 required, or alternatively, the production of additional receptors which display the specificity

421 to rMbST shown by pAb MU11, altogether with an increased affinity towards the target. As a

422 first approach, immunization with rMbST-mimicking MAPs bearing longer peptides will be

423 attempted, in order to determine the influence of the length of the displayed subunits in the

424 MAP on the avidity of the produced antibodies.

425

426

427

428

429

430

431

432

433

434

435

436

437

438

439

440

441

\subsection{Cross-reactivity analysis}

The interaction of the peptide-purified MU11 pAb with bST and somatotropins from other species (either native or recombinant; pST and rMeST), BSA, milk bovine proteins (lactoferrin, $\beta$-lactoglobulin and casein), as well as bovine proteins displaying a high sequence homology with bST (lactogen and prolactin) was assessed in a cross-reactivity study, using the mentioned molecules as competitors. No recognition was observed to any of the evaluated proteins, with the exception of rMeST, for which a $\mathrm{CR}$ value of $5.6 \%$ was obtained. The pituitary somatotropins which were not recognized by MU11, bST and pST, lack the $N$-terminus methionine present in the dipeptide displayed by the immunogen used for the production of the antibody (MF-MAP-SMCC-KLH), finding which points out the crucial role of this residue as antigenic determinant in the antibody-antigen binding event. Comparing the $N$-terminus amino acid sequence of $\operatorname{rMbST}\left(\mathrm{H}_{2} \mathrm{~N}-\right.$ MFPAMSLSGLFANAVLRA-) with that of rMeST ( $\mathrm{H}_{2} \mathrm{~N}-$ MFPAMPLSSLFANAVLRA-), whereas both recombinant proteins present the $N$-terminus methionine, two differences are encountered (highlighted in bold). Given the decreased interaction observed for rMeST with respect to $\mathrm{rMbST}$, serine at position 6 and/or glycine at position 9 appear to be also required for the antibody recognition. Presumably, the additional purification of the antibody using the 
$442 \mathrm{rMbST} \mathrm{N}$-terminus-mimicking linear peptide, would have contributed to the selection of

443 immunoglobulins which paratope would better fit an epitope containing these two amino

444 acids, therefore being specific for rMbST.

\section{4. Conclusions}

446 For decades the production of specific antibodies directed towards rMbST has not been

447 successfully accomplished as a consequence of an extremely minor difference (one amino

448 acid) encountered at the $N$-terminus of both proteins. In this paper, we report the generation

449 of a rabbit pAb displaying a high selectivity towards rMbST in a competitive antigen-coated

450 ELISA format. The immunogen employed for the production of the $\mathrm{pAb}$ consisted in an

$451 \mathrm{rMbST} N$-terminus-mimicking synthetic MAP displaying the first two amino acids of rMbST

452 conjugated to the carrier protein KLH. Further purification of the antibody using an rMbST

$453 \mathrm{~N}$-terminus-mimicking synthetic linear peptide significantly improved the performance of the

454 antibody. Further work is currently ongoing in order to produce rMbST-specific monoclonal

455 and polyclonal antibodies to efficiently develop an immunoassay that meets the requirements

456 both in terms of specificity and sensitivity to be implemented for the routine screening of

457 rMbST in milk.

\section{Acknowledgements}

459 This work was part of the $7^{\text {th }}$ Framework Programme Integrated Project Unique-Check

460 funded by the European Commission under Marie Curie Action, Industry-Academia

461 Partnerships and Pathways (IAPP, contract No 230667; www.qub.ac.uk/sites/Unique-Check/).

462 We thank Vincent Dehalu, Caroline Charlier, Michel Dubois, Mathieu Dubois, Nicolas Ralet,

463 Bruno Detry, Frédéric Larvor, Frédérique Courant, Soazig Elaudais, Ludivine Sérée,

464 Malgorzata Olejnik, Mary Josephine Morton, Andrea Leishman, Connor McMahon and 465 Richard Holland for excellent technical assistance and support. 
466

467

468

469

470

471

472

473

474

475

476

477

478

479

480

481

482

483

484

485

486

487

488

489

490

\section{References}

[1] R. Renaville, M. Hammadi, D. Portetelle, Domest. Anim Endocrinol. 23 (2002) 351-360.

[2] C. Brozos, Ph. Saratsis, C. Boscos, S.C. Kyriakis, P. Tsakalof, Small Ruminant Res. 29 (1998) 113-120.

[3] D.E. Bauman, Domest. Anim Endocrinol. 17 (1999) 101-116.

[4] Council Decision 1999/879/EC, Off. J. Eur. Commun. L25 (1999) 71-72.

[5] I.R. Dohoo, K. Leslie, L. DesCoteaux, A. Fredeen, P. Dowling, A. Preston, W. Shewfelt, Can. J. Vet. Res. 67 (2003) 241-251.

[6] I.R. Dohoo, L. DesCoteaux, K. Leslie, A. Fredeen, W. Shewfelt, A. Preston, P. Dowling, Can. J. Vet. Res. 67 (2003) 252-264.

[7] J. Davies, D. Davies, Microbiol. Mol. Biol. Rev. 74 (2010) 417-433.

[8] A. Daxenberger, B.H. Breier, H. Sauerwein, Analyst 123 (1998) 2429-2435.

[9] P.E. Clayton, I. Banerjee, P.G.Murray, A.G Renehan, Nat. Rev. Endocrinol. 7 (2011) 1124.

[10] A.J. Swerdlow, C.D Higgins, P. Adlard, M.A Preece, Lancet 360 (2002) 273-277.

[11] M.H. Le Breton, S. Rochereau-Roulet, G. Pinel, L. Bailly-Chouriberry, G. Rychen, S. Jurjanz, T. Goldmann, B. Le Bizec, Rapid Commun. Mass Spectrom. 22 (2008) 3130-3136.

[12] M.H. Le Breton, S. Rochereau-Roulet, G. Pinel, N. Cesbron, B. Le Bizec, Anal. Chim. Acta 637 (2009) 121-127.

[13] M.H. Le Breton, S. Rochereau-Roulet, S. Chéreau, G. Pinel, T. Delatour, B. Le Bizec, J. Agric. Food Chem. 58 (2010) 729-733.

[14] M.H. Le Breton, A. Beck-Henzelin, J. Richoz-Payot, S. Rochereau-Roulet, G. Pinel, T. Delatour, B. Le Bizec, Anal. Chim. Acta 672 (2010) 45-49.

[15] P.P. Groenewegen, B.W. McBride, J.H. Burton, T.H. Elsasser, J. Nutr. 120 (1990) 514520. 
491 [16] L. Castigliego, G. Iannone, G. Grifoni, R. Rosati, D. Gianfaldoni, A. Guidi, J. Dairy Res. $49274(2007) 79-85$.

493 [17] M.F. McGrath, G. Bogosian, A.C. Fabellar, R.L. Staub, J.L. Vicini, L.A. Widger, J. 494 Agric. Food Chem. 56 (2008) 7044-7048.

495 [18] D. Schams, F. Graf, J. Meyer, B. Graule, M. Mauthner, C. Wollny, J. Anim Sci. 69 496 (1991) 1583-1592.

497 [19] A. Guidi, L. Laricchia-Robbio, D. Gianfaldoni, R. Revoltella, G. Del Bono, Biosens. 498 Bioelectron. 16(2001) 971-977.

499 [20] M.G. Bremer, N.G. Smits, W. Haasnoot, M.W. Nielen, Analyst 135 (2010) 1147-1152.

500 [21] C.M. Zwickl, H.W. Smith, R.N. Tamura, P.H. Bick, J. Dairy Sci. 73 (1990) 2888-2895.

501 [22] S. Rochereau-Roulet, I. Gaudin, S. Chéreau, S. Prévost, G. André-Fontaine, G. Pinel, B. 502 Le Bizec, Anal. Chim. Acta 700 (2011) 189-193.

503 [23] M.H. Erhard, J. Kellner, S. Schmidhuber, D. Schams, U. Losch, J. Immunoassay 15 504 (1994) 1-19.

505 [24] P. Løvendahl, J. Adamsen, R. Lund, P. Lind, J. Anim Sci. 81 (2003) 1294-1299.

506 [25] T.H. Heutmekers, M.G. Bremer, W. Haasnoot, M.W. Nielen, Anal. Chim. Acta 586 507 (2007) 239-245.

508 [26] D.C. Hancock, N.J. O'Reilly, Methods Mol. Biol. 295 (2005) 13-26.

509 [27] L. Ma, Y.S. Liu, Y.Z. Ding, H.T. Chen, J. H. Zhou, W.Q. Liu, M. Wang, Zhang, J. 510 Hybridoma (Larchmt. ) 29 (2010) 409-412.

511 [28] M.Z. Atassi, B.Z. Dolimbek, L.E. Steward, K.R. Aoki, Immunol. Lett. 142 (2012) 2051227.

513 [29] J.P. Tam, Proc. Natl. Acad. Sci. U. S. A 85 (1988) 5409-5413.

514 [30] A. Pashov, G. Canziani, B. Monzavi-Karbassi, S.V. Kaveri, S. Macleod, R. Saha, M.

515 Perry, T.C. Vancott, T. Kieber-Emmons, J. Biol. Chem. 280 (2005) 28959-28965. 
516 [31] B. Mahajan, J.A. Berzofsky, R.A. Boykins, V. Majam, H. Zheng, R. Chattopadhyay, P.

517 de la Vega, J.K. Moch, J.D. Haynes, I.M. Belyakov, H.L. Nakhasi, S. Kumar, Infect. Immun.

$51878(2010) 4613-4624$.

519 [32] Y. Wu, Q. Zhang, D. Sales, A.E. Bianco, A. Craig, Vaccine 28 (2010) 6425-6435.

520 [33] T. Fujiki, A. Tsuji, S.E. Matsumoto, M. Yamashita, K. Teruya, S. Shirahata, Y.

521 Katakura, Biosci. Biotechnol. Biochem. 74 (2010) 1836-1840.

522 [34] J.P. Tam, J. Immunol. Methods 196 (1996) 17-32.

523 [35] L.I. González-Villaseñor, T.T. Chen, Mar. Biotechnol. (NY) 1 (1999) 211-220.

524 [36] G.Z. Wang, X.D. Tang, M.H. Lu, J.H. Gao, G.P. Liang, N. Li, C.Z. Li, Y.Y. Wu, L.

525 Chen, Y.L. Cao, D.C. Fang, S.M. Yang, Cancer Prev. Res. (Phila) 4 (2011) 1285-1295.

526 [37] R. Renaville, C. Bertozzi, D. Portelle, in: Ministère des Classes moyenes et de 527 l'Agriculture (Ed.), Nouvelles méthodes analytiques pour la détection de substances à activité 528 hormonale et de tranquillisants en production animale, Brussels, 2002, chapter III. 


\section{Table and Figure captions}

530 Table 1. Pituitary and commercial recombinant bST specifications.

531 Table 2. Polyclonal antibody production.

532 Table 3. Summary of the preliminary characterization of the pAbs by antigen-coated ELISA.

533 Figure 1. Chemical structure of the rMbST $N$-terminus-mimicking immunizing synthetic 534 multiple antigen peptide (MAP).

535 Figure 2. Recognition towards rMbST and bST coating antigens $\left(4 \mu \mathrm{g} \mathrm{mL}^{-1}\right)$ displayed by 536 different pAbs.

537 Figure 3. Competitive experiment performed with the protein A purified pAb MU11 using $538 \mathrm{bST}$ and $\mathrm{rMbST}$ as competitor reagents (empty and filled bars, respectively). rMbST coating 539 antigen concentrations were $1(\boldsymbol{\square}), 2(\boldsymbol{\square}), 4(\boldsymbol{\square}), 8(\boldsymbol{\square})$ and $16(\boldsymbol{\square}) \mu \mathrm{g} / \mathrm{mL}$, and they were 540 combined with the following antibody dilutions: 1/500,1/500,1/1000,1/1500 and 1/2000, 541 respectively. Each value represents the average of three independent experiments.

542 Figure 4. Standard curves for $\mathrm{rMbST}$ and bST obtained with the peptide-purified pAb 543 MU11. 


\section{Analytica Chimica Acta}

545

Highlights

546

547

548 - Production of polyclonal antibodies directed to recombinant methionyl bovine

549 somatotropin (rMbST)

550 - Multiple antigen peptide mimicking rMbST $N$-terminus used as immunogen

551 - Immunodiscrimination between native and recombinant bovine somatotropins by

$552 \quad$ ELISA

553

554

555

556 
Table 1. Pituitary and commercial recombinant bST specifications

\begin{tabular}{|c|c|c|c|c|c|}
\hline Somatotropin & $\begin{array}{c}\text { aa } \\
\text { length }\end{array}$ & $\begin{array}{l}\text { Molecular } \\
\text { weight }\end{array}$ & $\begin{array}{c}\text { Position } \\
1\end{array}$ & $\begin{array}{c}\text { Position } \\
1 / 2\end{array}$ & $\begin{array}{c}\text { Position } \\
126 / 127\end{array}$ \\
\hline bST variant 1 & 191 & $21788 \mathrm{Da}$ & Ala- ${ }^{c}$ & -Phe- ${ }^{\mathrm{d}}$ & $-\mathrm{Val}^{\mathrm{e}}{ }^{\mathrm{e}}$ \\
\hline $\mathrm{bST}$ variant $2^{\mathrm{a}}$ & 191 & $21802 \mathrm{Da}$ & Ala- & -Phe- & -Leu- ${ }^{\mathrm{f}}$ \\
\hline bST variant 3 & 190 & $21717 \mathrm{Da}$ & & Phe- & -Val- \\
\hline bST variant 4 & 190 & $21731 \mathrm{Da}$ & & Phe- & -Leu- \\
\hline $\begin{array}{c}\text { rMbST } \\
\left(\operatorname{Posilac}\left({ }^{\circledR}\right)^{b}\right.\end{array}$ & 191 & $21851 \mathrm{Da}$ & Met- ${ }^{g}$ & -Phe- & -Leu- \\
\hline
\end{tabular}

${ }^{a}$ Majority isoform of pituitary bST. ${ }^{b}$ Commercial recombinant bST most commonly used worldwide. ${ }^{\mathrm{c}}$ Alanine. ${ }^{\mathrm{d}}$ Phenylalanine. ${ }^{\mathrm{e}}$ Valine. ${ }^{\mathrm{f}}$ Leucine. ${ }^{\mathrm{g}}$ Methionine.

557

558

559 
Table 2. Polyclonal antibody production

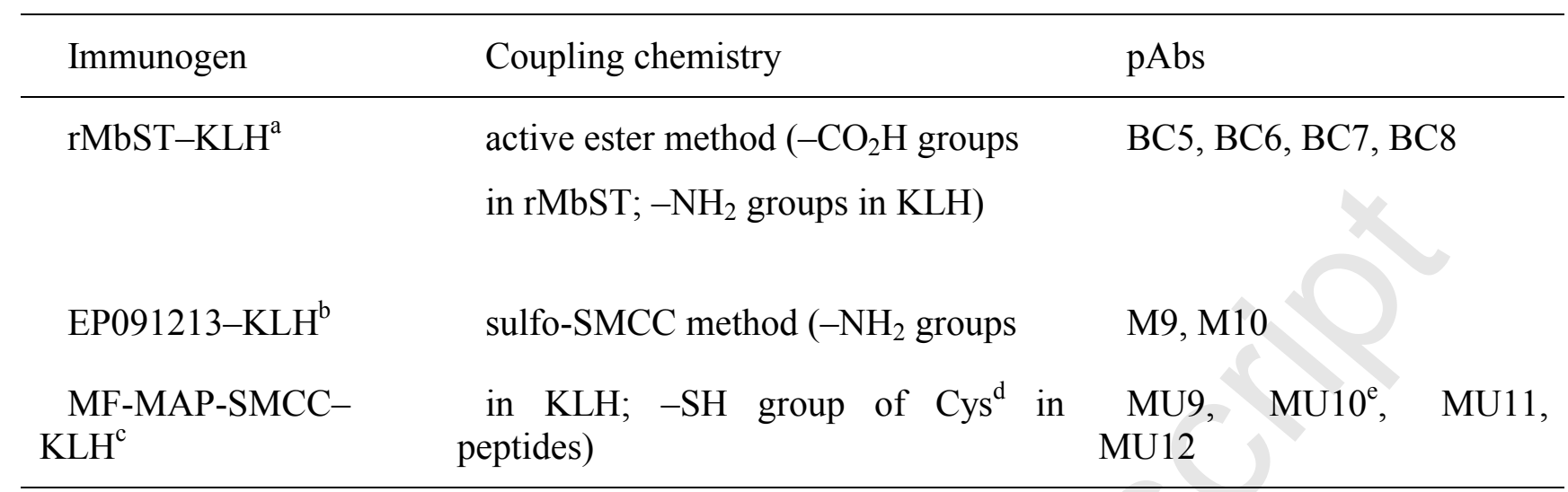

${ }^{\mathrm{a}}$ Complete recombinant methionyl bST. ${ }^{\mathrm{b}}$ Synthetic rMbST $N$-terminus-mimicking linear peptide. ${ }^{\text {c }}$ Synthetic rMbST $N$-terminus-mimicking multiple antigen peptide. ${ }^{\mathrm{d}}$ Cysteine. ${ }^{\mathrm{e}}$ This rabbit died during the immunization process.

560

561

562

563

564

565

566 
Table 3. Summary of the preliminary characterization of the pAbs by antigen-coated ELISA

\begin{tabular}{llcc}
\hline Immunogen & pAb & Binding to rMbST & Binding to bST \\
\hline rMbST-KLH & BC5 & $+++^{\mathrm{a}}$ & +++ \\
& BC6 & +++ & +++ \\
& BC7 & +++ & +++ \\
EP091213-KLH & BC8 & +++ & +++ \\
& M9 & + & - \\
MF-MAP-SMCC-KLH & M10 & - & + \\
& MU9 & + & - \\
& MU11 & + & +++ \\
\hline
\end{tabular}

${ }^{a}$ Results corresponding to the analysis of the raw pAbs used without any further purification. Binding to coating antigens ( $\mathrm{rMbST}$ and bST at $1 \mu \mathrm{g} \mathrm{mL}^{-1}$ ) corresponding to a 1/500 dilution of the pAbs expressed as: $(+++)$ strong $(\mathrm{AU} \geq 2) ;(++)$ medium $(1 \leq \mathrm{AU}<2) ;(+)$ low $(0.3 \leq \mathrm{AU}<1) ;(-)$ negligible $(\mathrm{AU}<0.3)$. Those pAbs providing a signal intensity for rMbST at least $0.2 \mathrm{UA}$ above that observed towards bST have been highlighted in bold. 
Immunodiscrimination between closely structurally related proteins
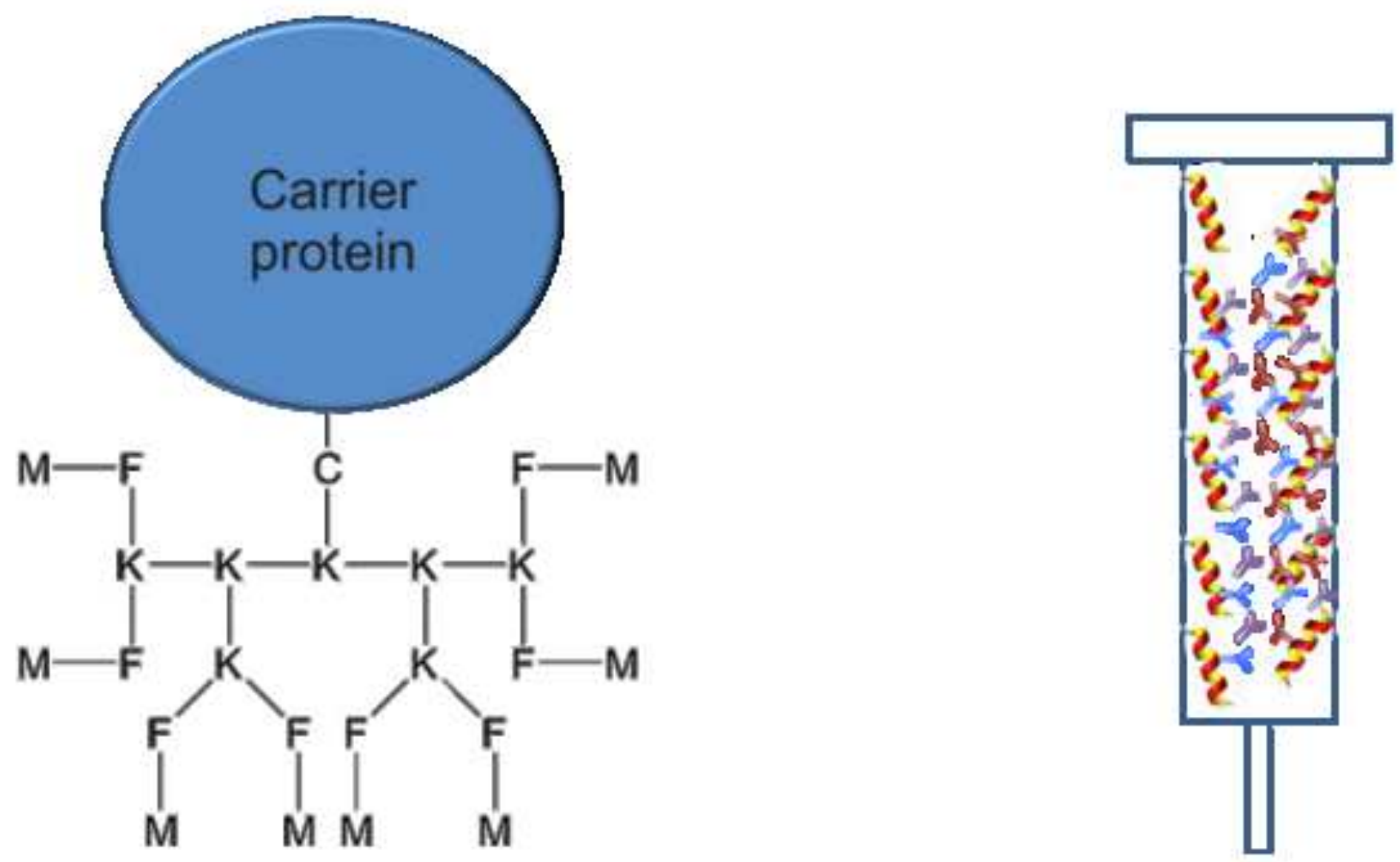

MAP-based immunogen

Monovalent peptide-based affinity purification of antibodies 


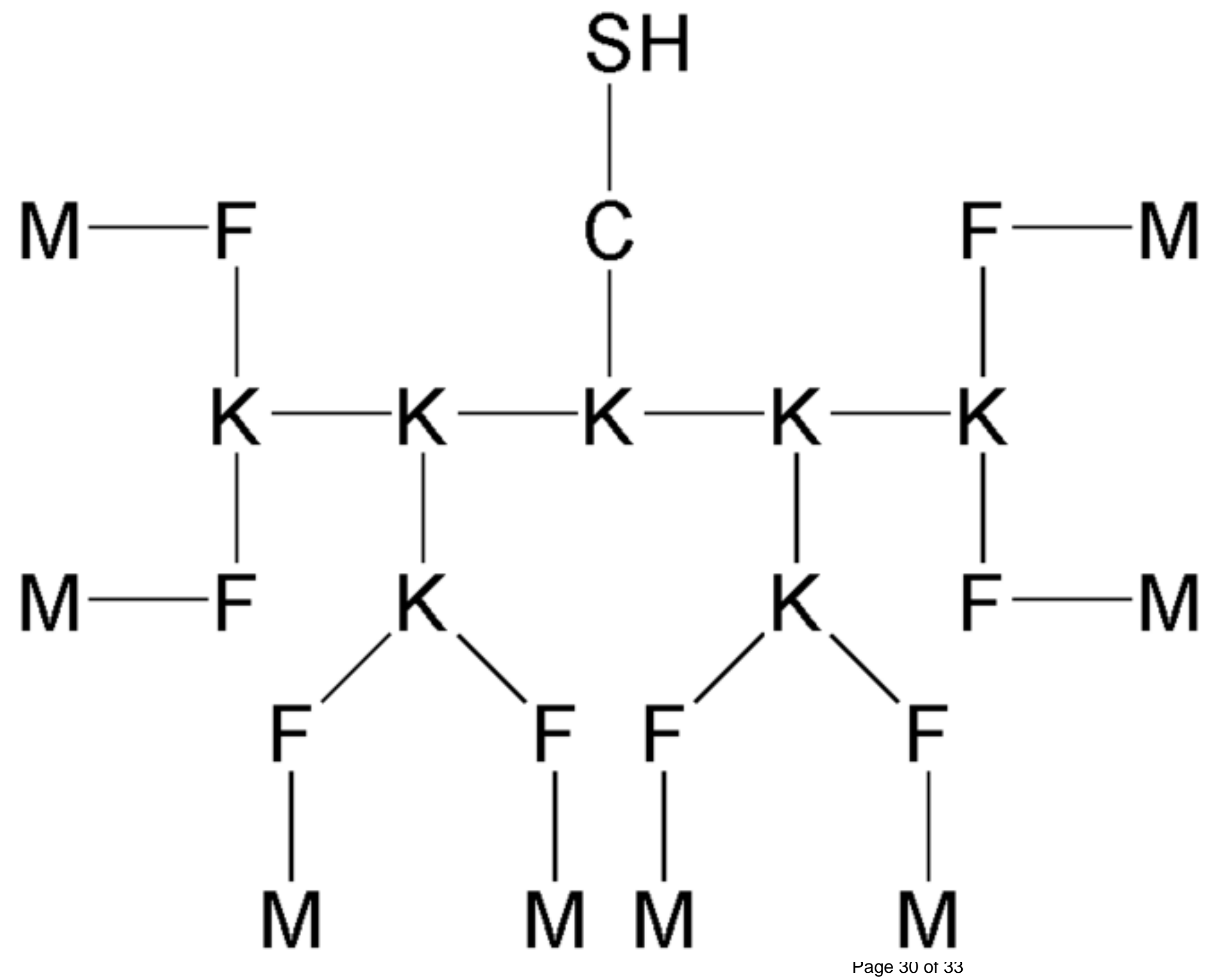

rage 30 or 33 


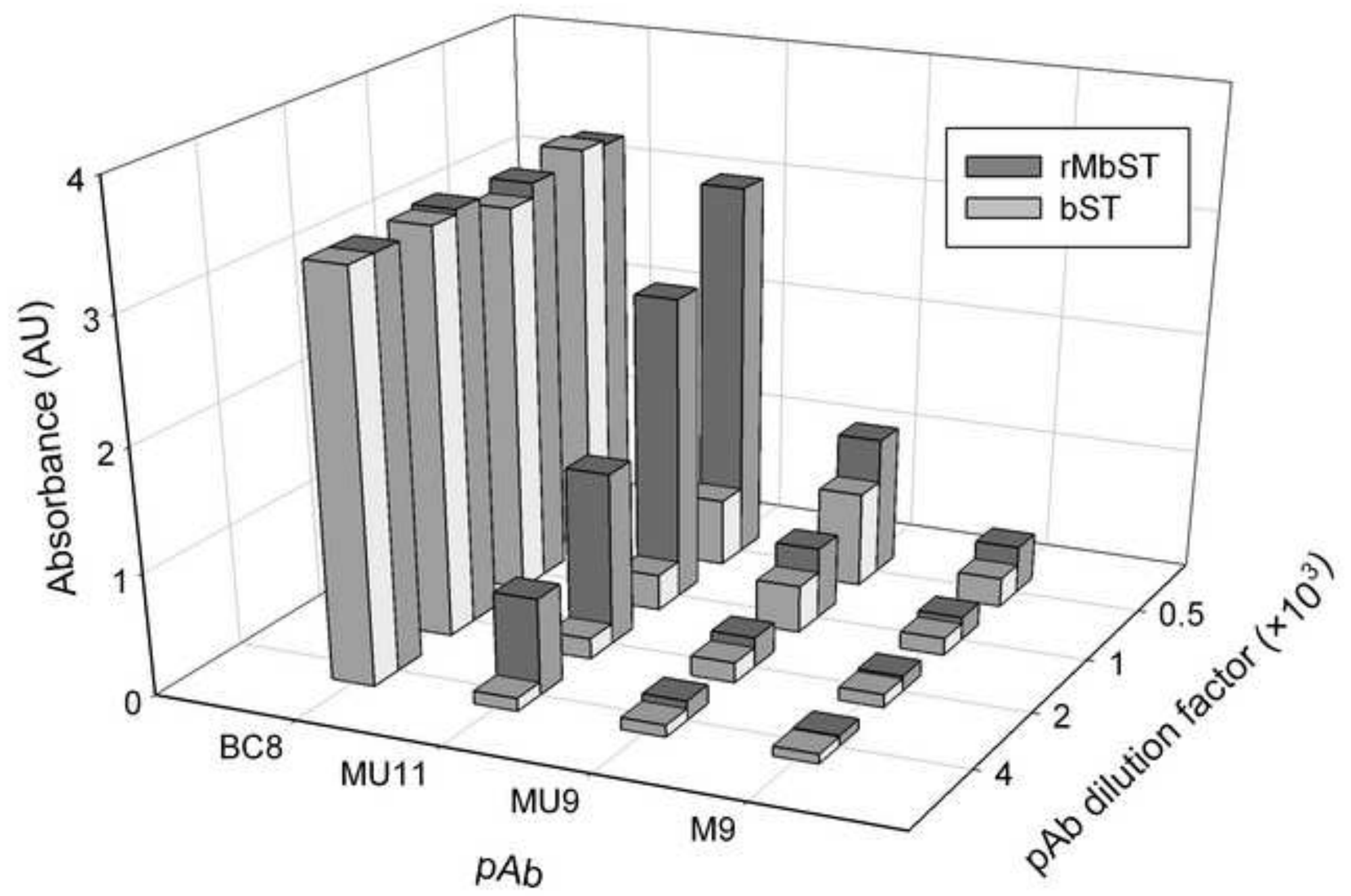

Page 31 of 33 


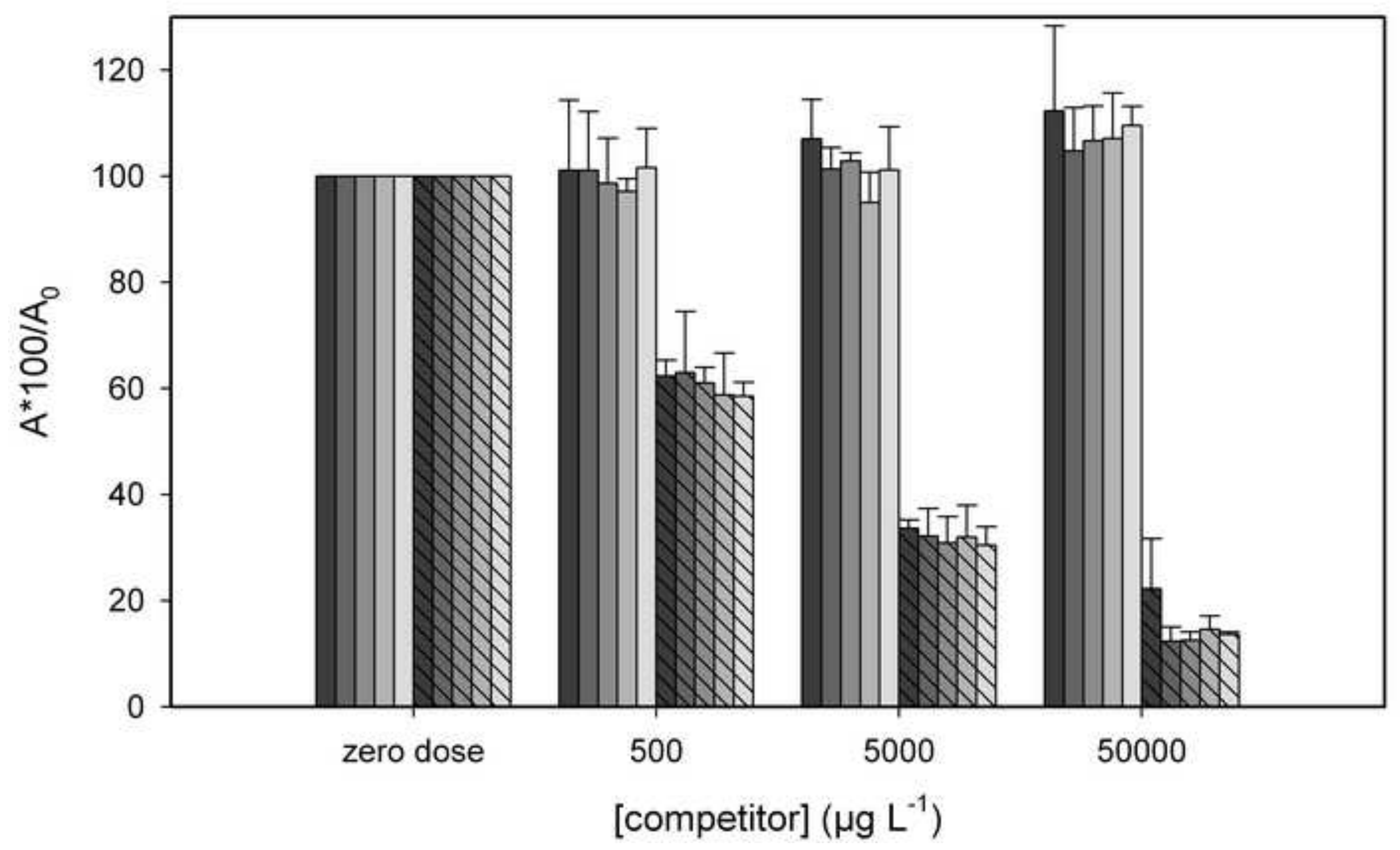

Page 32 of 33 


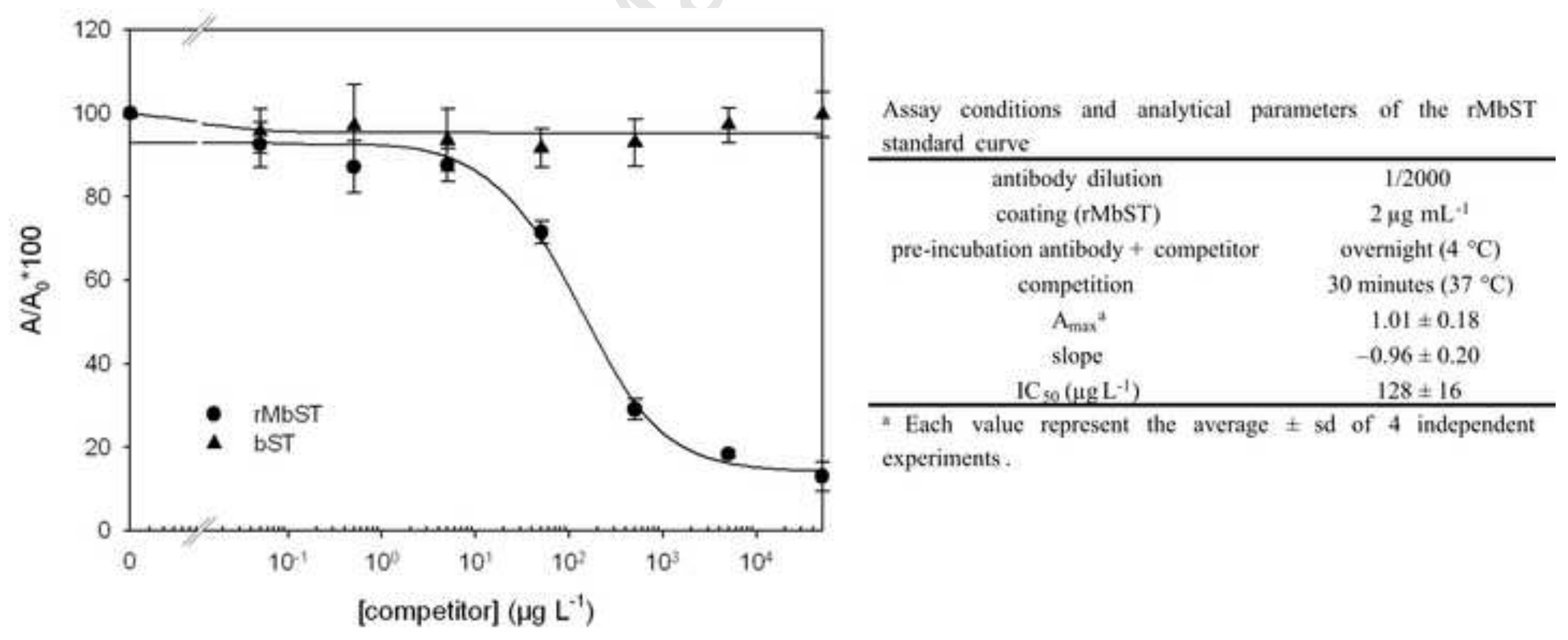

